\title{
EFEKTIVITAS MEDIASI DALAM PERKARA PERCERAIAN DI PENGADILAN AGAMA KARAWANG
}

\author{
Farhan Asyhadi
}

\author{
Universitas Buana Perjuangan Karawang
}

Email: farhan.asyhadi@ubpkarawang.ac.id

\begin{abstract}
Abstrak
Penelitian ini mengkaji Efektivitas Mediasi Dalam Perkara Perceraian di Pengadilan Agama Karawang. Tujuan penelitian ini adalah mengungkap tingkat keberhasilan mediasi di Pengadilan Agama Karawang, faktor-faktor yang menjadi penghambat keberhasilan mediasi di Pengadilan Agama Karawang. Penelitian ini adalah penelitian lapangan yang bersifat deskriptif kualitatif, dengan mengambil lokasi di Pengadilan Agama Karawang. Pendekatan yang digunakan adalah pendekatan yuridis, teologis normatif, dan pendekatan sosiologis. Adapun pengumpulan data yang diperoleh di lapangan dengan teknik observasi, wawancara,/interview dan dokumentasi. Data yang dikumpulkan kemudian diolah dengan menggunakan analisis reduksi data, penyajian data dan penarikan kesimpulan. Berdasarkan hasil penelitian efektivitas mediasi dalam perkara perceraian di Pengadilan Agama Karawang, sudah sejalan dengan Peraturan Mahkamah Agung (PERMA) Nomor 1 Tahun 2016 Tentang Prosedur Mediasi di Pengadilan. Mediator kesulitan mendamaikan para pihak disebabkan karena beberapa faktor dan menunjukan bahwa mediasi belum efektif. Faktor-faktor penyebabnya adalah: Tingkat kepatuhan masyarakat yang menjalani proses mediasi sangat rendah. Fasilitas dan sarana mediasi di Pengadilan Agama Karawang masih kurang memadai baik dari segi ruang mediasi maupun fasilitas penunjang didalamnya dan faktor iktikad para pihak serta faktor budaya masyarakat karawang yang takut berperkara di Pengadilan Agama Karawang sehingga banyaknya putusan yang diputus verstek (perkara yang putus tanpa dihadiri salah satu pihak).
\end{abstract}

Kata Kunci: Efektivitas, Mediasi, Perceraian.

The law is the most important system in society to regulate life in relation to an order that is always moving both evolutionarily and revolutionarily. Order is regulated in the law itself including transcendental order, social/community order and political order. Private law which is a provision or regulation relating to someone's personal with others, or also civil law has a broad scope in its regulation. One area of law that regulates the relationships between individuals in society with certain means. The current classification of private law includes: Family law, Property law, Material law, Engagement law, and inheritance law. Critical study of private law that has prevailed in Indonesia using philoshopy (philosophical) methods, then the basis for thinking should be the philosophy of Pancasila. As is known that Pancasila is the source of all sources of Indonesian state law. This is considered appropriate given the philosophy of Pancasila is the spirit of the struggle of the nation's fighters, as a unifying tool, from previously divided by a region / region, race, ethnicity, class and religion.

Keyword: Private Law, Philosophical,

Pancasila. 


\section{PENDAHULUAN}

Penyelesaian sengketa dapat dilakukan melalui dua proses yaitu proses litigasi di dalam pengadilan dan proses penyelesaian sengketa melalui kerja sama (kooperatif) di luar pengadilan. Proses penyelesaian sengketa di luar pengadilan menghasilkan kesepakatan yang bersifat memuaskan kedua belah pihak (win-win solution), dijamin kerahasiaannnya, menghindari lambatnya prosedur administrasi, penyelesaian masalah secara komprehensif dalam kebersamaan dan tetap menjaga hubungan baik. Penyelesaian sengketa di luar pengadilan tersebut dinamakan Alternative Dispute Resolution (ADR) yang dalam bahasa Indonesia diartikan sebagai Pilihan Penyelesaian Sengketa (PPS) atau Mekanisme Alternatif Penyelesaian Sengketa (MAPS) melalui cara konsultasi, negosiasi, mediasi, arbiterase, dan model-model lainnya ${ }^{1}$.

Mediasi merupakan salah satu jenis alternatif penyelesaian sengketa

1 Rachmadi Usman, Pilihan Penyelesaian Sengketa Di Luar Pengadilan, PT. Citra Aditya Bakti, Bandung, 2003, hlm. 3. non litigasi melalui proses perundingan pemecahan masalah di mana pihak luar yang tidak memihak (impartial) dan netral bekerja dengan pihak yang bersengketa untuk membantu mereka memperoleh kesepakatan perjanjian yang memuaskan kedua belah pihak (win-win solution). Berbeda dengan hakim atau arbiter, mediator tidak memiliki wewenang untuk memutuskan sengketa antara para pihak. Namun dalam hal ini para pihak menguasakan kepada mediator untuk membantu mereka menyelesikan masalah diantara mereka. Asumsinya, pihak ketiga akan mampu mengubah kekuatan dan dinamika sosial hubungan konflik dengan cara mempengaruhi tingkah laku pribadi para pihak dengan memberikan pengetahuan atau informasi yang lebih efektif. Dengan demikian, mediator dapat membantu para pihak untuk menyelesaikan persoalan yang dipersengketakan.

Mahkamah Agung telah menerapkan kebijakan integrasi proses mediasi ke dalam tata beracara perdata di pengadilan dengan tujuan untuk menekan jumlah perkara yang naik ke tingkat banding maupun kasasi agar 
tidak terjadi penumpukan perkara melalui Surat Edaran Mahkamah Agung (SEMA) Nomor 1 Tahun 2002 Tentang Pemberdayaan Lembaga Perdamaian. Kemudian dirubah dengan Peraturan Mahkamah Agung (PERMA) Nomor 2 Tahun 2003 Tentang Prosedur Mediasi Di Pengadilan. Revisi berikutnya melalui Peraturan Mahkamah Agung (PERMA) Nomor 1 Tahun 2008 Tentang Prosedur Mediasi Di Pengadilan dan yang terbaru adalah Peraturan Mahkamah Agung (PERMA) Nomor 1 Tahun 2016 Tentang Prosedur Mediasi Di Pengadilan.

Dalam pelaksanaannya, mediasi di pengadilan sering kali mengalami kegagalan atau tidak tercapainya kesepakatan damai antara para pihak yang berperkara. Pelaksanaan Peraturan Mahkamah Agung tersebut dapat dikatakan kurang begitu optimal sehingga apa yang diharapkan belum dapat tercapai. Produk yang dihasilkan peradilan dalam penyelesaian perkara yang diajukan kepadanya didominasi oleh putusan konvensional yang bercorak menang atau kalah (winning or losing). Jarang ditemukannya penyelesaian berdasarkan konsep sama-sama menang (win-win solution).
Dalam konteks pelaksanaan Peraturan Mahkamah Agung (PERMA) Nomor 1 Tahun 2016 Tentang Prosedur Mediasi Di Pengadilan, Pengadilan Agama Karawang telah menerbitkan 2 (dua) Surat Keputusan diantaranya Surat Keputusan Ketua Pengadilan Agama Karawang Nomor: W.10-A7/54/KP.04.6/I/2019 tentang Penetapan Nama Hakim Mediator tertanggal 04 Januari 2019 dan Surat Keputusan Ketua Pengadilan Agama Karawang Nomor: W.10A7/651/Kp.01.2/III/2019 tentang pengangkatan mediator non hakim pada Pengadilan Agama Karawang. Mediator yang ditetapkan dalam surat keputusan tersebut sebanyak 14 mediator hakim dan 2 mediator dari pensiunan pegawai Pengadilan Agama.

Berdasarkan Laporan Mediasi Pengadilan Agama Karawang periode bulan Januari 2019, tercatat sebanyak 67 perkara yang masuk untuk mediasi. Dari 67 perkara yang masuk tersebut kemudian dilaksanakan mediasi dan hasilnya ada 4 (empat) perkara yang berhasil dimediasi.

\section{PERMASALAHAN}

Berdasarkan latar belakang di atas, permasalahan yang penulis rumuskan 
adalah faktor-faktor apa saja yang mempengaruhi keberhasilan mediasi di Pengadilan Agama Karawang?

\section{METODE PENELITIAN}

Penelitian ini merupakan penelitian lapangan dimana metode pendekatan yang digunakan adalah yuridis-empiris. Spesifikasi penelitian bersifat deskriptif analitis, yakni dengan memberikan gambaran terhadap masalah yang diangkat dan memberikan analisis dari masalah sehingga mampu memberikan jawaban atas permasalahan tersebut.

Metode pengumpulan data dalam penelitian ini adalah menggunakan teknik observasi berupa kegiatan interview atau wawancara. Lalu data yang telah dikumpulkan diolah dan dianalisis menggunakan analisis reduksi data, penyajian data dan penarikan kesimpulan.

\section{PEMBAHASAN}

\section{A. Tinjauan Yuridis PERMA Nomor}

\section{Tahun 2016}

Kekuasaan dan kewenangan Mahkamah Agung terkait pengawasan secara tidak langsung ialah dengan membuat peraturan yang ditegaskan pada angka 2 huruf c Penjelasan
Umum Undang-undang Nomor 48

Tahun 2009 Tentang Perubahan atas Undang-undang Nomor 14 Tahun 1985 Tentang Mahkamah Agung yang berbunyi "Membuat peraturan sebagai pelengkap untuk mengisi kekurangan atau kekosongan hukum yang diperlukan bagi kelancaran jalannya peradilan".

Mengenai kategorinya, Peraturan Mahkamah Agung (PERMA) jika ditinjau dari segi ketentuan perundangundangan sebagaimana yang termuat dalam Pasal 8 ayat (1) Undang-undang Nomor 12 Tahun 2011 Tentang Pembentukan Peraturan Perundangundangan, maka termasuk dalam salah satu jenis ketentuan peraturan perundang-undangan, yang mana dapat dijelaskan sebagai berikut:

"Jenis Peraturan Perundangundangan selain sebagaimana dimaksud dalam Pasal 7 ayat (1) mencakup peraturan yang ditetapkan oleh Majelis Permusyawaratan Rakyat, Dewan Perwakilan Rakyat, Dewan Perwakilan Daerah, Mahkamah Agung, Mahkamah Konstitusi, Badan Pemeriksa Keuangan, Komisi Yudisial, Bank Indonesia, Menteri, badan, lembaga, atau komisi yang setingkat yang dibentuk dengan Undang-Undang atau Pemerintah atas perintah Undang-Undang, Dewan Perwakilan Rakyat Daerah Provinsi, Gubernur, Dewan Perwakilan Rakyat Daerah 
Bupati/Walikota, Kepala Desa atau yang setingkat."2

Menjadi salah satu dasar diaturnya mediasi ini, juga tercantum dalam konsideran Peraturan Mahkamah Agung (PERMA) Nomor 1 Tahun 2016 Tentang Prosedur Mediasi di Pengadilan, yakni Reglement Indonesia yang diperbaharui (HIR) Staatsblad 1941 Nomor 44 dan Reglement Hukum Acara untuk daerah luar Jawa dan Madura (RBg) Staatsblad 1927 Nomor 227. Pada Pasal 130 ayat (1) menjelaskan bahwa:

"Pada hari pertama sidang pengadilan yang telah ditentukan, maka pengadilan negeri dengan pertolongan ketua mencoba akan mendamaikan pihak yang bersengketa".

Selanjutnya pada ayat (2) mengatur:

"Jika Perdamaian yang demikian itu terjadi, maka tentang hal itu pada waktu bersidan diperbuat sebuah akte, dengan nama kedua belah pihak diwajibkan untuk mencukupi perjanjian yang diperbuat itu; maka surat (akte) itu akan berkekuatan dan akan dilakukan sebagai putusan hakim biasa".

Ayat (2) pada pasal $130 \mathrm{HIR}$ tersebut menjelaskan bahwa, apabila terjadi perdamaian pada saat mediasi, maka kedua belah pihak akan dibuatkan akta

2 Pasal 8 ayat (1) Undang-undang Nomor 12 Tahun 2011 Tentang Pembentukan Peraturan Perundang-undangan perdamaian yang berkekuatan hukum tetap yang kemudian akan berlaku sebagai hukum yang setara dengan putusan pengadilan. Sebab ketentuan dalam Peraturan Mahkamah Agung (PERMA) Nomor 1 Tahun 2016 Tentang Prosedur Mediasi di Pengadilan memiliki kekuatan mengikat dan daya paksa bagi para pihak yang berperkara di Pengadilan.

Peraturan Mahkamah Agung (PERMA) Nomor 1 Tahun 2016 mengartikan mediasi merupakan cara penyelesaian sengketa secara damai yang tepat, efektif dan dapat membuka akses yang lebih luas kepada para pihak untuk memperoleh penyelesaian yang memuaskan serta berkeadilan. ${ }^{3}$

Sebagaimana yang termuat dalam Pasal 3 ayat (3) di Peraturan Mahkamah Agung (PERMA) Nomor 1 Tahun 2016 bahwa, hakim pemeriksa perkara yang tidak memerintahkan para pihak untuk menempuh mediasi sehingga para pihak tidak melakukan mediasi telah melanggar ketentuan peraturan perundang-undangan yang mengatur mengenai mediasi di Pengadilan.

\footnotetext{
${ }^{3}$ Ketua Mahkamah Agung Republik Indonesia, Peraturan Mahkamah Agung Republik Indonesia Nomor 1 Tahun 2016 Tentang Prosedur Mediasi di Pengadilan, hlm. 1.
} 
Begitu pula dalam ayat (4) Pasal 3 Peraturan Mahkamah Agung (PERMA) ini menyebutkan bahwa, dalam hal terjadi pelanggaran terhadap ketentuan sebagaimana dimaksud pada ayat (3), apabila diajukan upaya hukum maka Pengadilan Tingkat Banding atau Mahkamah Agung dengan putusan sela memerintahkan Pengadilan Tingkat Pertama untuk melakukan proses mediasi. Sehingga tidak menjalankan mediasi sesuai dengan peraturan PERMA Nomor 1 Tahun 2016 tersebut dapat mengakibatkan putusan batal demi hukum.

\section{B.Efektivitas dan Faktor-Faktor yang} Mempengaruhi Keberhasilan Mediasi di Pengadilan Agama

\section{Karawang}

Pelaksanaan mediasi di pengadilan hakekatnya adalah penegakan hukum terhadap Peraturan Mahkamah Agung (PERMA) Nomor 1 Tahun 2016 Tentang Prosedur Mediasi di Pengadilan. Menurut Soerjono Soekanto, penegakan hukum adalah kegiatan menyerasikan hubungan nilainilai yang terjabarkan dalam kaidahkaidah/pandangan nilai yang mantap dan mengejawantahkan dengan sikap dan tindakan sebagai rangkaian penjabaran nilai akhir untuk menciptakan, memelihara dan mempertahankan kedamaian pergaulan hidup. ${ }^{4}$

Keberhasilan pelaksanaan mediasi di Pengadilan Agama Karawang sebagai bentuk penegakan hukum terhadap Peraturan Mahkamah Agung (PERMA) Nomor 1 Tahun 2016 Tentang Prosedur Mediasi di Pengadilan dipengaruhi oleh faktorfaktor sebagai berikut:

\section{Faktor Peraturan Perundang- undangan}

Faktor peraturan perundangundangan mempengaruhi keberhasilan pelaksanaan mediasi di Pengadilan Agama Karawang, karena merupakan payung hukum yang mengatur tentang mediasi. Peraturan tersebut adalah Peraturan Mahkamah Agung (PERMA) Nomor 1 Tahun 2016 Tentang Prosedur Mediasi di Pengadilan yang menggantikan beberapa peraturan sebelumya

\footnotetext{
4 Soerjono Soekanto, Faktor-Faktor Yang Mempengaruhi Penegakan Hukum, Raja Grafindo Persada, Jakarta, 2004, hlm. 42.
} 
yaitu Surat Edaran Mahkamah Agung (SEMA) Nomor 1 Tahun 2002 Tentang Pemberdayaan Lembaga Perdamaian, Peraturan Mahkamah Agung (PERMA) Nomor 2 Tahun 2003 Tentang Prosedur Mediasi Di Pengadilan dan Peraturan Mahkamah Agung (PERMA) Nomor 1 Tahun 2008 Tentang Prosedur Mediasi Di Pengadilan. Perubahan beberapa kali terhadap Peraturan Mahkamah Agung (PERMA) tentang mediasi mengindikasikan adanya keseriusan Mahkamah Agung untuk mengintegrasikan proses mediasi dalam sistem peradilan khususnya dalam penangan perkara perdata di pengadilan dan juga bentuk penyempurnaan terhadap aturan pelaksanaan mediasi.

Ada beberapa fokus penekanan dari Peraturan Mahkamah Agung (PERMA) Nomor 1 Tahun 2016 yang berbeda dibandingkan dengan Peraturan Mahkamah Agung (PERMA) Nomor 1 Tahun 2008 yaitu sebagai berikut: ${ }^{5}$

5 Kelompok Kerja Alternatif Penyelesaian a) Pengaturan tentang alasan-alasan yang sah tidak menghadiri mediasi untuk kemudian dapat diwakilkan kepada Kuasa Hukum. Alasan-alasan tersebut adalah kondisi kesehatan yang tidak memungkinkan hadir dalam pertemuan mediasi berdasarkan surat keterangan dokter, di bawah pengampuan, mempunyai tempat tinggal, kediaman atau kedudukan di luar negeri, dan menjalankan tugas negara, tuntutan profesi atau pekerjaan yang tidak dapat ditinggalkan.

b) Pengaturan tentang iktikad baik dalam mediasi, meliputi kriteria tidak beriktikad baik, bentuk sanksi jika Penggugat tidak beriktikad baik, bentuk

Sengketa Mahkamah Agung RI. Buku Tanya Jawab Mediasi di Pengadilan Berdasarkan PERMA Nomor 1 Tahun 2016 tentang Prosedur Mediasi di Pengadilan, 2017, hal.4. 
sanksi jika Tergugat tidak beriktikad baik, bentuk sanksi jika Penggugat dan Tergugat tidak beriktikad baik, mekanisme penetapan pihak atau para pihak yang tidak beriktikad baik dan mekanisme pelaksanaan sanksi.

c) Menambah kewajiban Hakim Pemeriksa Perkara untuk menjelaskan tentang prosedur mediasi dan penandatanganan formulir terkait penjelasan mediasi serta kesiapan untuk beriktikad baik dalam menempuh mediasi.

d) Perubahan lama waktu mediasi dari sebelumnya diatur selama 40 (empat puluh) hari menjadi 30 (tiga puluh) hari. Perubahan juga dilakukan terhadap lama waktu perpanjangan mediasi dari sebelumnya hanya 14 (empat belas) hari menjadi 30 (tiga puluh) hari.

e) Diperkenalkannya kesepakatan sebagian (partial settlement) sebagai hasil mediasi dan masuk dalam kategori mediasi yang berhasil serta tata cara menyelesaikan sebagian lainnya yang belum disepakati melalui mediasi. Kesepakatan sebagian ini dapat berupa kesepakatan sebagian pihak (subyek) dan kesepakatan sebagian permasalahan (obyek).

\section{Faktor Peraturan Perundang- undangan}

Keberhasilan pelaksanaan mediasi di Pengadilan Agama Karawang juga dipengaruhi oleh para penegak hukum yang secara langsung menangani mediasi. Para penegak hukum yang dimaksud adalah hakim dan mediator. Hakim memiliki posisi cukup strategis dalam mencapai keberhasilan mediasi. Hakim yang menangani perkara wajib 
memerintahkan para pihak untuk menempuh mediasi dan wajib menyebutkan dalam pertimbangan putusan bahwa perkara telah diupayakan perdamaian melalui mediasi dan mencantumkan nama mediator, hal ini sebagaimana diatur dalam pasal 3 Ayat (2) dan ayat (3) Peraturan Mahkamah Agung (PERMA) Nomor 1 Tahun 2016. Hakim yang menangani perkara memutuskan siapa yang akan menjadi mediator dalam proses mediasi sesuai dengan kehendak para pihak yang berperkara.

Kompetensi mediator dalam hal ini adalah kualifikasi, skill dan keahlian mediator, yang secara ideal harus sesuai dengan kebutuhan para pihak, yang mana latar belakang keilmuannya dapat dijadikan sebagai alat untuk membantu para pihak memecahkan permasalahan dan memberikan solusi atas permasalahan yang terjadi.

Sebagaimana dalam perkra perceraian, yang dilatarbelakangi berbagai faktor yang memicu perselisihan, mulai dari persoalan ekonomi, psikologi, kerohanian, dan konflik-konflik lainnya. Keterlibatan mediator yang memiliki kualifikasi keilmuan yang signifikan dengan penyebab konflik akan memudahkan para pihak untuk memecahkan masalah dan menemukan solusi yang tepat, misalnya saja, perselisihan yang dilatarbelakangi konflik ekonomi, dimana suami menjadi pihak tergugat dengan alasan ketidak mampuan memberikan nafkah. Untuk mengetahui suami pada kondisi yang tidak sanggup atau hanya sekedar lalai, maka dibutuhkan pakar ekonomi untuk memberikan solusi yang terbaik untuk kedua belah pihak.

Dalam hal pertengkaran yang terus menerus, di mana kedua belah pihak saling mengklaim, pihak lainlah yang bersalah, lalai atau tidak dapat memenuhi tugasnya. Hal demikian banyak terjadi dalam proses mediasi, yang membutuhkan mediator yang ahli dalam bidang psikologi atau kerohanian untuk memberikan solusi yang tepat untuk kedua belah pihak. 
Oleh karena itu, terkait mediator, dalam prosedur pelaksanaan mediasi di Pengadilan, Peraturan Mahkamah Agung (PERMA) Nomor 1 Tahun 2016 mengatur beberapa syarat di antaranya dalam ayat

Ketentuan Umum Peraturan Mahkamah Agung (PERMA) Nomor 1 Tahun 2016:

"Mediator adalah hakim atau pihak lain yang memiliki Sertifikat Mediator sebagai pihak netral yang membantu Para Pihak dalam proses perundingan guna mencari berbagai kemungkinan penyelesaian sengketa tanpa menggunakan cara memutus atau memaksakan sebuah penyelesaian."

Untuk memperoleh sertifikat, mediator harus mengikuti pelatihan sertifikasi mediator yang diselenggarakan oleh Mahkamah Agung atau lembaga yang terakreditasi oleh Mahkamah Agung. Aturan ini sudah ideal adanya, sebab untuk menjadi seorang mediator perlu kriteria dan keahlian khusus, akan tetapi dalam peraturan tersebut tidak menyinggung persoalan latar belakang keilmuan, dalam artian semua orang bisa menjadi mediator, dan yang paling berpeluang menjadi mediator adalah hakim dengan latar belakang keilmuan hukum. Sedangkan hal ihwal yang menjadi latar belakang konflik dalam pernikahan buan hanya persoalan hukum yang dapat diselesaikan oleh ahli dan praktisi hukum.

$$
\text { Pengadilan Agama }
$$

Karawang, secara kuantitas memiliki 14 mediator yang keseluruhan merupakan hakim Pengadilan Agama Karawang sesuai Surat Keputusan Ketua Pengadilan Agama Karawang Nomor: W.10A7/54/KP.04.6/I/2019 tentang Penetapan Nama Hakim Mediator tertanggal 04 Januari 2019, berikut nama-nama hakim mediator tersebut. 


\begin{tabular}{|l|l|l|l|}
\hline No & Nama Mediator Hakim & Jabatan & Pengalaman \\
\hline 1 & Drs. H. M Yusuf SH., MH & Ketua & $15-10-1995$ \\
\hline 2 & $\begin{array}{l}\text { Drs. H. Mohammad Yamin, } \\
\text { SH., MH }\end{array}$ & $\begin{array}{l}\text { Wakil } \\
\text { Ketua }\end{array}$ & $12-07-1995$ \\
\hline 3 & Drs. Abid, MH & Hakim & $30-04-1995$ \\
\hline 4 & Dra. Hj. Erawati, SH., MH & Hakim & $31-07-1995$ \\
\hline 5 & H. Abdillah, SH., MH & Hakim & $04-09-1995$ \\
\hline 6 & Drs. Hasan Basri, SH., MH & Hakim & $01-09-1995$ \\
\hline 7 & Dra. Ratna Jumila, SH., MH & Hakim & $01-09-1995$ \\
\hline 8 & Dra. Hj. Siti Sabihah, SH., MH & Hakim & $10-05-1999$ \\
\hline 9 & Drs. H. Ma'mun Sholeh, MH & Hakim & $15-10-1990$ \\
\hline 10 & Dra. Elfina Fitriani & Hakim & $06-09-1995$ \\
\hline 11 & Drs. Candra Triswangga & Hakim & $01-05-1999$ \\
\hline 12 & Drs. Humaidi Yusuf & Hakim & $29-04-1999$ \\
\hline 13 & Drs. Subarkah, SH., MH & Hakim & $27-04-2005$ \\
\hline 14 & Dra. Hj. Dadah Holidah, MH & Hakim & $05-01-1998$ \\
\hline & ı craı ıııı puı suı aı nepuıusaı neıua reıyauıaı Agaııa
\end{tabular}

Karawang Nomor : W.10-A7/651/Kp.01.2/III/2019 tentang pengangkatan mediator non hakim pada Pengadilan Agama Karawang, yaitu:

\begin{tabular}{|l|l|l|}
\hline No & Nama Mediator & Keterangan \\
\hline 1 & Dra. Nur'aini Saladin, SH & Bersertifikat \\
\hline 2 & A.Supandi, S.Ag & Bersertifikat \\
\hline
\end{tabular}

Pada tahun 2018, Pengadilan Agama Karawang menerima sebanyak 3. 987 perkara yang terdiri dari 3.360 perkara gugatan dan 627 perkara Permohonan dengan rincian berdasarkan jenis perkara sebagai berikut: 


\begin{tabular}{|c|c|c|c|c|}
\hline No & JENIS PERKARA & \multicolumn{3}{|c|}{ PENERIMAAN } \\
\hline & & BAYAR & PRODEO & JUMLAH \\
\hline 1 & Izin Poligami & 7 & 0 & 7 Perkara \\
\hline 2 & Pembatalan Perkawinan & 1 & 0 & 1 Perkara \\
\hline 3 & Cerai Thalak & 992 & 13 & 1.005 Perkara \\
\hline 4 & Cerai Gugat & 2.255 & 49 & 2.304 Perkara \\
\hline 5 & Harta Bersama & 7 & 0 & 7 Perkara \\
\hline 6 & Penguasaan Anak & 6 & 0 & 6 Perkara \\
\hline 7 & Pengesahan Anak & 2 & 0 & 2 Perkara \\
\hline 8 & Perwalian & 30 & 0 & 30 Perkara \\
\hline 9 & $\begin{array}{lll}\text { Penunjukan } & \text { orang } & \text { lain } \\
\text { sebagai wali } & & \end{array}$ & 1 & 0 & 1 Perkara \\
\hline 10 & Asal Usul Anak & 23 & 2 & 25 Perkara \\
\hline 11 & Pengangkatan Anak & 2 & 0 & 2 Perkara \\
\hline 12 & Itsbat Nikah & 140 & 391 & 531 Perkara \\
\hline 13 & Dispensasi Nikah & 26 & 0 & 26 Perkara \\
\hline 14 & Wali Adhol & 5 & 0 & 5 Perkara \\
\hline 15 & Ekonomi Syariah & 3 & 0 & 3 Perkara \\
\hline 16 & Kewarisan & 4 & 0 & 4 Perkara \\
\hline 17 & Hibah & 1 & 0 & 1 Perkara \\
\hline 18 & Penetapan Ahli Waris & 26 & 0 & 26 Perkara \\
\hline 19 & Lain-lain & 1 & 0 & 1 Perkara \\
\hline & JUMLAH & 3.532 & 455 & 3.987 Perkara \\
\hline
\end{tabular}

Penerimaan perkara yang masuk sejak 2018, perkara terbanyak diperoleh dari cerai gugat sejumlah 2.304 perkara, perolehan ini belum ditambah dari sisa hasil perkara tahun lalu yang belum diputus oleh hakim. Beban perkara banyak mengakibatkan para hakim tidak memiliki waktu untuk memediasi para pihak sehingga diperlukan adanya pihak luar yang mempunyai kompetensi dalam bidang mediasi. 
Salah satu hasil wawancara penulis dengan mediator yaitu Bapak A. Sopandi, S.Ag, beliau mengatakan ada beberapa teknik yang dilakukan mediator agar bisa berhasil dalam proses mediasi diantaranya dengan memberikan nasehat sentuhan rohani kepada para pihak yang dimediasi, terapi obat hati, memberikan alternatif solusi permasalahan dalam perkara yang disengketakan, menyusun draf perjanjian perdamaian dan mencari titik persamaan antar pihak serta menghindari perbedaan ${ }^{6}$.

Keterampilan dan kelihaian membaca duduk perkara yang dimediasi adalah hal mutlak yang harus dimiliki oleh seorang mediator demi tercapainya kesepakatan damai antara pihak yang berperkara. Dalam hal kemampuan memediasi suatu perkara, sertifikasi mediator juga menjadi tolak ukur yang secara formal diakui dalam PERMA

6 Wawancara penulis dengan mediator non hakim Bapak A. Supandi, S.Ag. pada hari Jumat tanggal 9 Agustus 2019 di Ruang Mediasi Pengadilan Agama Karawang. mediasi.

\section{Faktor Peraturan Perundang- undangan}

Ketersediaan sarana/fasilitas mediasi juga menjadi faktor yang mempengaruhi keberhasilan pelaksanaan mediasi. Pengadilan Agama Karawang telah menyediakan ruang khusus mediasi. Mediasi perkara dapat dilakukan di ruang mediasi pengadilan maupun di tempat lain diluar pengadilan sesuai kesepakatan para pihak. Apabila proses mediasi menggunakan mediator hakim atau pegawai pengadilan, maka mediasi wajib dilakukan di pengadilan dan tidak dikenakan biaya. Hal ini sesuai dengan ketentuan Pasal 4 ayat (1), (2), (3), dan (4) PERMA Nomor 1 Tahun 2016 Tentang Prosedur Mediasi di Pengadilan.

Selain sarana berupa ruangan beserta kelengkapannya, ada fasilitas pendukung mediasi yang diatur dalam Pasal 5 Ayat (3) PERMA Nomor 1 Tahun 2016 Tentang Prosedur Mediasi di Pengadilan yaitu mediasi dapat 
dilakukan dengan menggunakan komunikasi audio visual jarak jauh yang memungkinkan para pihak dapat saling melihat dan mendengar secara langsung serta ikut berpartisipasi dalam pertemuan mediasi. Untuk saat ini Pengadilan Agama Karawang belum menyediakan alat komunikasi audio visual jarak jauh seperti yang dimaksud, hal ini dikarenakan sejauh ini mediasi yang dilakukan langsung dan dihadiri secara langsung oleh para pihak dan mediator. Secara keseluruhan sarana dan prasarana mediasi di Pengadilan Agama Karawang cukup memadai. Ruangan yang digunakan untuk melakukan mediasi sangat layak sehingga dapat menunjang jalannya proses mediasi yang dilakukan.

\section{Faktor Peraturan Perundang- undangan}

Faktor internal yang berasal dari para pihak juga menjadi faktor yang mempengaruhi keberhasilan pelaksanaan mediasi. Harus ada iktikad baik berupa motivasi dan keinginan yang tulus dari para pihak untuk menempuh mediasi, karena mediasi hanya akan berhasil apabila para pihak yang bersengketa mempunyai niat yang sama untuk berdamai.

Tujuan mediasi adalah menyelesaikan sengketa secara damai, oleh karena itu tanpa adanya iktikad baik dari para pihak, perdamaian tidak akan tercapai. Untuk mencegah adanya pihak yang bersikap tidak kooperatif, iktikad baik para pihak merupakan kunci keberhasilan mediasi. Prinsip iktikad baik ini dapat menjadi tolok ukur bagi para pihak yang bersengketa untuk meneruskan atau tidak meneruskan menempuh perdamaian melalui jalan mediasi di Pengadilan. Hasil akhir dari perdamaian juga harus berdasarkan kesepakatan dari kedua belah pihak. Apabila pihak penggugat dinyatakan tidak beriktikad baik dalam proses mediasi maka gugatan dinyatakan tidak dapat diterima oleh Hakim pemeriksa perkara serta dikenai kewajiban pembayaran biaya 
mediasi. Sebaliknya apabila pihak tergugat yang dinyatakan tidak beriktikad baik dikenai kewajiban pembayaran biaya mediasi. Adapun apabila para pihak secara bersama-sama dinyatakan tidak beriktikad baik oleh mediator, gugatan dinyatakan tidak dapat diterima oleh Hakim pemeriksa perkara tanpa penghukuman biaya mediasi.

\section{Faktor Peraturan Perundang- undangan}

Faktor budaya masyarakat juga menjadi faktor yang mempengaruhi keberhasilan pelaksanaan mediasi. Masyarakat Karawang yang berasal dari pedesaan dengan mata pencaharian petani dan buruh mempunyai budaya musyawarah dalam menyelesaiakan persengketaan. Proses mediasi secara kultural dan alami tersebut dibantu oleh tokoh masyarakat dan tokoh agama. Dengan demikian menurut penulis, adanya budaya tersebut maka mediasi yang dipandu oleh mediator di pengadilan juga akan sangat potensial mencapai kesepakatan damai.

\section{KESIMPULAN}

Berdasarkan uraian pembahasan penulis, dapat disimpulkan bahwa faktor-faktor yang mempengaruhi keberhasilan mediasi di Pengadilan Agama Karawang meliputi faktor peraturan perundang-undangan berupa Peraturan Mahkamah Agung (PERMA) Nomor 1 Tahun 2016 Tentang Prosedur Mediasi di Pengadilan, faktor penegak hukum yaitu hakim dan mediator, faktor sarana/fasilitas mediasi, faktor iktikad para pihak dan faktor budaya masyarakat.

\section{SARAN}

Pelaksanaan mediasi Pengadilan Agama Karawang sudah berjalan dengan baik, untuk meningkatan jumlah keberhasilan mediasi penulis memberikan saran sebagai berikut:

A. Perlunya sosialisasi pentingnya mediasi kepada para pihak yang berperkara beserta akibat hukumnya agar mediasi yang dilakukan tidak hanya dianggap formalitas belaka yang berakibat pada gagalnya 
pencapaian kesepakatan damai dalam mediasi.

B. Menambah fasilitas mediasi berupa alat komunikasi audio visual jarak jauh yang memungkinkan para pihak dapat saling melihat dan mendengar secara langsung serta ikut berpartisipasi dalam pertemuan mediasi.

\section{DAFTAR PUSTAKA}

\section{A. Buku}

Rachmadi Usman, Pilihan Penyelesaian Sengketa Di Luar Pengadilan, PT. Citra Aditya Bakti, Bandung, 2003.

Soerjono Soekanto, Faktor-Faktor Yang Mempengaruhi

Penegakan Hukum, Raja

Grafindo Persada, Jakarta, 2004.

Sudikno Mertokusumo, Hukum Acara Perdata Indonesia, Liberty, Yogyakarta, 2002.

\section{B. Peraturan Perundang-undangan}

Undang-Undang Dasar Negara Republik Indonesia 1945

Undang-Undang Nomor 12 Tahun 2011 Tentang Pembentukan Peraturan Perundangundangan.

HIR (Het Herziene Inlands Reglement)

PERMA Nomor 1 Tahun 2016 tentang Prosedur Mediasi di Pengadilan.

\section{Sumber Lainnya}

$\begin{array}{rr}\text { Kelompok Kerja } & \text { Alternatif } \\ \text { Penyelesaian } & \text { Sengketa }\end{array}$


Mahkamah Agung RI, Buku

Tanya Jawab Mediasi di

Pengadilan Berdasarkan

PERMA Nomor 1 Tahun

2016 tentang Prosedur

Mediasi di Pengadilan,

2017.

Surat Keputusan Ketua Pengadilan

Agama Karawang Nomor:

W.10-A7/54/KP.04.6/I/2019

Tentang Penetapan Nama

Hakim Di Pengadilan Agama

Karawang

Surat Keputusan Ketua Pengadilan

Agama Karawang Nomor:

W.10-

A7/651/Kp.01.2/III/2019

Tentang Susunan Mediator

Non Hakim Di Pengadilan

Agama Karawang. 